\title{
Keanekaragaman Musuh Alami Koloni Lepidotrigona terminata Smith (Hymenoptera: Apidae: Meliponinae)
}

\author{
Diversity of Natural Enemies in the Colony of Lepidotrigona \\ terminata Smith (Hymenoptera: Apidae: Meliponinae)
}

\author{
ANGGUN WICAKSONO ${ }^{1 *}$, TRI ATMOWIDI ${ }^{2}$, WINDRA PRIAWANDIPUTRA ${ }^{2}$ \\ ${ }^{\text {I} P r o g r a m ~ S t u d i ~ P e n d i d i k a n ~ B i o l o g i, ~ F a k u l t a s ~ I l m u ~ T a r b i y a h ~ d a n ~ K e g u r u a n, ~ U n i v e r s i t a s ~ I s l a m ~ N e g e r i ~ R a d e n ~ F a t a h, ~}$ \\ Palembang 30126, Indonesia \\ ${ }^{2}$ Departemen Biologi, Fakultas Matemetika dan Ilmu Pengetahuan Alam, IPB University, Bogor 16680, Indonesia
}

Diterima 17 Februari 2020/Disetujui 23 September 2020

\begin{abstract}
The study on diversity of natural enemies of stingless bee Lepidotrigona terminata had been conducted from october to december 2016 in the field Laboratory, Department of Biology, Bogor Agricultural University of West Java. All presumed natural enemis were identified along with their habitat. There were 14 species natural enemies of stingless bee $L$. terminata identified from 687 individuals collected in this research, i.e. Arachnida, Reptilia, and Insecta. Our observation, indicated that spider, ants, and lizard were the potential predator for the stingless bee. The results from this study are expected to addknowledge in conserving and cultivation the stingless bees.
\end{abstract}

Key words: Diversity, Natural enemies, Lepidotrigona terminata, Predator, Stingless bee, West Java

\section{PENDAHULUAN}

Lepidotrigona terminata termasuk jenis lebah tak bersengat (stingless bees) yang terdistribusi luas di Indonesia meliputi Jawa, Sumatra, Sulawesi, dan Kalimantan (Rasmussen 2008; Smith 2012). Lebah tak bersengat $L$. terminata ini mudah dikenali dari thorak yang mempunyai susunan rambut-rambut membentuk cincin berwarna kuning atau putih dibagian luar mesoscutum dan rambut kuning semisirkular pada mesosculetum (Schwarz 1939; Smith 2012). Habitat L. terminata menghuni hutan primer, hutan terbuka, dan juga pemukiman penduduk (Inoue et al. 1985; Banziger et al. 2011; Hamid et al. 2016). Biasanya sarang L. terminata berada di dalam lubang atau celah pohon dan bebatuan dengan pintu masuk sarang (entrance) berbentuk tabung memanjang seperti corong atau terompet dengan ujungnya yang melebar berwarna coklat terang dengan tekstur lunak dan lengket (Chinh et al. 2005; Banziger et al. 2011; Kelly et al. 2014).

Struktur sarang lebah tak bersengat termasuk $L$. terminata terdiri dari pintu masuk, cerumen, sel-sel polen, sel-sel madu, sel-sel anakan, dan batumen.

*Penulis korespondensi:

E-mail: gun.wicak.gw@gmail.com
Cerumen adalah campuran dari resin dan lilin untuk membangun sel-sel sarang dan digunakan untuk melindungi bagian dalam sarang. Batumen berupa campuran resin dan material lainnya yang digunakan sebagai pelindung dari sinar matahari langsung dan predator (Starr and Sakagami 1987; Michener 2013). Walaupun terdapat sistem pertahanan pada struktur sarang, musuh alami masih menjadi permasalahan dalam budidaya lebah tak bersengat.

Musuh alami didefinisikan sebagai organisme alamiah yang bersifat mengganggu ataupun membunuh hewan lainnya seperti predator, parasit, dan pathogen (Estes et al. 2001). Predator dan parasit dapat mengurangi produktivitas lebah dan madu, mempengaruhi struktur dan komposisi sarang, serta dapat menyebabkan kematian koloni (Pangestika 2016). Mekanisme pertahanan pada lebah Trigona berupa resin pada mulut sarang dan serangan berupa gigitan (De Bruijn and Sommeijer 1997; Lehmberg et al. 2008; Leonhardt et al. 2010). Gigitan yang agresif biasanya dilakukan oleh lebah tak bersengat sebagai mekanisme pertahanan terhadap predator (Lehmberg et al. 2008; Shackleton et al. 2015).

Predator merupakan hewan yang bersifat karnivora atau memangsa hewan lain. Terdapat beberapa predator yang menyerang koloni lebah di antaranya tawon, semut, dan laba-laba (Kumar et al. 2012). Laba-laba dan semut termasuk hewan karnivora yang 
termasuk predator (Subyanto et al. 1991; Pangestika et al. 2016). Selain itu, semut juga menjadi predator yang membahayakan lebah tak bersengat di luar dan dalam sarang (Lehmberg et al. 2008). Parasit merupakan organisme yang hidupnya bergantung kepada mahkluk hidup lainnya. Parasit yang umum ditemukan pada lebah madu (lebah bersengat) antara lain, tungau, kutu, ngengat, dan kumbang (Strauss et al. 2013). Oleh karena itu, tujuan penelitian ini adalah menganalisis keanekaragaman dan mendeskripsikan spesies musuh alami pada koloni $L$. terminata. Pengetahuan terhadap jenis musuh alami stingless bee ini dapat digunakan untuk memformulasikan majemen penanganan musuh alami tersebut sehingga memaksimalkan budidaya lebah tak bersengat.

\section{BAHAN DAN METODE}

Waktu dan Tempat Penelitian. Penelitian ini dilakukan pada bulan Oktober sampai Desember 2016 bertempat di Laboratorium lapangan, Divisi Biosistematika dan Ekologi Hewan, Departemen Biologi, Institut Pertanian Bogor. Satu sarang $L$. terminata berada didalam rumah kaca yang dikelilingi vegetasi pepohonan dan rerumputan yang berjarak $\pm 500 \mathrm{~m}$ dari aktifitas manusia. Pengoleksian musuh alami dilakukan selama 10 hari pada bulan Oktober mulai pukul 07.00-17.00 WIB disekitar sarang lebah. Sampel yang dikoleksi kemudian diidentifikasi di Laboratorium Biosistematika dan Ekologi Hewan, Departemen Biologi, Fakultas Matematika dan Ilmu Pengetahuan Alam, Institut Pertanian Bogor.

Koleksi dan Mounting Spesimen Musuh Alami. Musuh alami dari L. terminata dikoleksi dengan menggunakan metode perangkap sweep net, pitfall trap, dan penangkapan langsung. Jumlah individu musuh alami hanya yang berada berjarak $1 \mathrm{~m}$ dari sarang lebah dikoleksi kemudian dihitung dengan menggunakan counter. Musuh alami yang dikoleksi, diawetkan dalam botol berisikan ethanol $70 \%$ dan dilakukan proses mounting. Proses mounting dilakukan untuk mempermudah proses identifikasi. Spesimen kemudian disimpan pada oven dengan suhu $35^{\circ} \mathrm{C}$ selama satu minggu dan dimasukkan ke dalam freezer pada suhu $-15^{\circ} \mathrm{C}$ selama satu minggu. Individu musuh alami yang diperoleh diidentifikasi berdasarkan karakter morfologi sampai level spesies.

Identifikasi Spesimen Musuh Alami. Spesimen musuh alami dari $L$. terminata diidentifikasi berdasarkan karakter morfologi meliputi kepala, toraks, abdomen. Pengamatan karakter morfologi pada kelompok hewan dengan ukuran yang kecil dengan menggunakan mikroskop Nikon Model C-LEDS dikombinasikan dengan kamera Optilab di
Laboratorium Biosistematika dan Ekologi Hewan, Departemen Biologi, Fakultas Matematika dan Ilmu Pengetahuan Alam, Institut Pertanian Bogor. Identifikasi individu musuh alami dideskripsikan menurut Subyanto et al. (1991) dan Borror et al. (1992).

Analisis Statistik. Keanekaragaman musuh alami dianalisis dengan menggunakan indeks ShannonWiener $\left(\mathrm{H}^{\prime}\right)$, indeks kemerataan $\left(\mathrm{J}^{\prime}\right)$, dan indeks Dominansi (D) (Krebs 1999) dengan rumus:

$$
\begin{aligned}
& \mathrm{H}^{\prime}=-\Sigma \text { pi ln pi } \\
& \mathrm{J}^{\prime}=\mathrm{H}^{\prime} / \ln \mathrm{s} \\
& \mathrm{D}=1[\mathrm{ni}(\mathrm{ni}-1)] /[\mathrm{N}(\mathrm{N}-1)]
\end{aligned}
$$

Pi menunjukkan proporsi individu yang ditemukan pada spesies "i", ln menunjukkan logaritma alami, s menunjukkan jumlah spesies, ni menunjukkan kepadatan populasi spesies "i", $\mathrm{N}$ menunjukkan kepadatan populasi total dari semua spesies.

\section{HASIL}

Berdasarkan hasil pengamatan ditemukan sebanyak 14 spesies musuh alami yang termasuk dalam 3 taksa, yaitu Arachnida (7 spesies), Reptilia (2 spesies), dan Insekta (5 spesies). Spesies musuh alami lebah L. terminata dapat dilihat pada Tabel 1.

Pseudeuophrys sp., Heliophanus sp., Plexippus paykuli, dan Marpissa sp. termasuk kedalam kelas Arachnida, famili Salticidae. Pseudeuophrys sp. memiliki tubuh berwarna coklat dengan panjang

\begin{tabular}{|c|c|c|c|}
\hline Kelas & Famili & Spesies & Interaksi \\
\hline \multirow[t]{7}{*}{ Arachnida } & Salticidae & Pseudeuophrys sp. & Memangsa \\
\hline & & Heliophanus sp. & Memangsa \\
\hline & & Plexippus paykuli & Memangsa \\
\hline & & Marpissa sp. & Memangsa \\
\hline & Araneidae & Argiope versicolor & Memangsa \\
\hline & Theridiidae & $\begin{array}{l}\text { Parasteatoda } \\
\text { tepidariorum }\end{array}$ & Memangsa \\
\hline & Agelenida & Tegenaria sp. & Memangsa \\
\hline \multirow[t]{5}{*}{ Insekta } & Termitidae & $\begin{array}{l}\text { Nasutitermes } \\
\text { javanicus }\end{array}$ & Merusak sarang \\
\hline & Formicidae & Paratrechina sp. & $\begin{array}{l}\text { Memangsa dan } \\
\text { mengambil } \\
\text { madu }\end{array}$ \\
\hline & & Polyrhachis sp. & Memangsa \\
\hline & & $\begin{array}{l}\text { Paratrechina } \\
\text { longicornis }\end{array}$ & $\begin{array}{l}\text { Memangsa dan } \\
\text { mengambil } \\
\text { madu }\end{array}$ \\
\hline & Vespidae & $\begin{array}{l}\text { Rhynchium } \\
\text { haemorrhoidale }\end{array}$ & $\begin{array}{l}\text { Memangsa dan } \\
\text { mengambil } \\
\text { madu }\end{array}$ \\
\hline \multirow[t]{2}{*}{ Reptilia } & Gekkonidae & $\begin{array}{l}\text { Hemidactylus } \\
\text { frenatus }\end{array}$ & Memangsa \\
\hline & & $\begin{array}{l}\text { Hemidactylus } \\
\text { garnotii }\end{array}$ & Memangsa \\
\hline
\end{tabular}
tubuh $3.89 \mathrm{~mm}$. Mata berjumlah delapan tersusun

Tabel 1. Spesies musuh alami dan interaksinya terhadap lebah 
dalam dua baris dengan pola susunan 4-4. Mata anterior bagian tengah sama besar dengan mata anterior bagian lateral. Mata posterior bagian tengah lebih besar daripada mata posterior bagian lateral. Sefalothoraks berbentuk membulat dengan warna coklat kehitaman. Abdomen membulat panjang dengan spinneret dibagian ventral abdomen dengan bentuk lonjong. Tungkai berwarna coklat terang dengan warna hitam pada ujung sendinya (Gambar 1).

Heliophanus sp. memiliki tubuh berwarna oranye sampai kemerahan dengan corak garis dan bintik biru dibagian sefalotoraks dan abdomen. Panjang tubuh $3.81 \mathrm{~mm}$ dengan pedicel berbentuk panjang bewarna coklat. Mata berjumlah delapan tersusun dalam dua baris dengan pola susunan 4-4 sejajar. Mata posterior tengah besar, sedangkan anterior bagian tengah sama besar dengan mata anterior bagian lateral. Sefalothoraks berbentuk persegi panjang dengan corak garis berwarna biru dibagian posterior dan lateral. Abdomen berbentuk lonjong dengan bintik biru dan hitam yang membentuk pola semisirkular dibagian ujungnya. Spinneret dibagian ventral abdomen dengan bentuk dan ukuran yang sama. Tungkai berwarna coklat dengan pola garis hitam dibagian femur (Gambar 1).

Plexippus paykuli memiliki tubuh didominasi warna kecoklatan dengan panjang $3.37 \mathrm{~mm}$. Mata berjumlah delapan tersusun dalam dua baris dengan pola susunan 4-4 sejajar dan mata posterior tengah dua buah berukuran besar. Sefalothoraks berbentuk lonjong berwarna hitam di belakang mata dengan ukuran lebih besar dari abdomen. Abdomen berbentuk oval coklat kehitaman dengan rambut-rambut yang membentuk pola membulat. Spinneret dibagian ventral abdomen. Tungkai berwarna coklat terang dengan rambut-rambut tebal. Spesies ini menyukai habitat serasah, lipatan kayu, dan celah-celah tanaman (Gambar 1).

Marpissa sp. memiliki tubuh berwarna kehitaman dengan rambut-rambut putih diseluruh bagian tubuhnya dan memiliki panjang $8.21 \mathrm{~mm}$. Mata berjumlah delapan tersusun dalam dua baris dengan pola susunan 4-4. Mata posterior tengah besar dan mata posterior lateral diatas thorak. Sefalothoraks berbentuk persegi panjang hitam kecoklatan dengan garis coklat besar dibagian tengah. Sefalothoraks lebih besar dari abdomen. Abdomen hitam kecoklatan berbentuk segilima dengan ujung meruncing. Spinneret dibagian ventral abdomen. Tungkai hitam kecoklatan dan bagian trochanter berwarna putih pucat (Gambar 1).

Argiope versicolor termasuk kedalam family Araneidae dengan tubuh berwarna coklat dengan garis hijau dan kuning dibagian abdomen dengan panjang tubuh $20 \mathrm{~mm}$. Mata berjumlah delapan yang tersusun dalam dua baris dengan pola 4-4, jarak mata posterior dan anterior bagian lateral sangat dekat, dua mata tengah anterior dan posterior tersusun sejajar dan berukuran sama. Sepalothoraks berbentuk oval dan lebar dengan rambut-rambut halus berwarna perak. Tungkai sangat panjang berwarna kecoklatan dengan tiga kuku dibagian ujungnya. Abdomen berbentuk segilima berwarna hitam dengan garis kuning dan hijau yang tersusun horizontal. Spinneret terletak di bagian ujung ventral abdomen (Gambar 1). Spesies
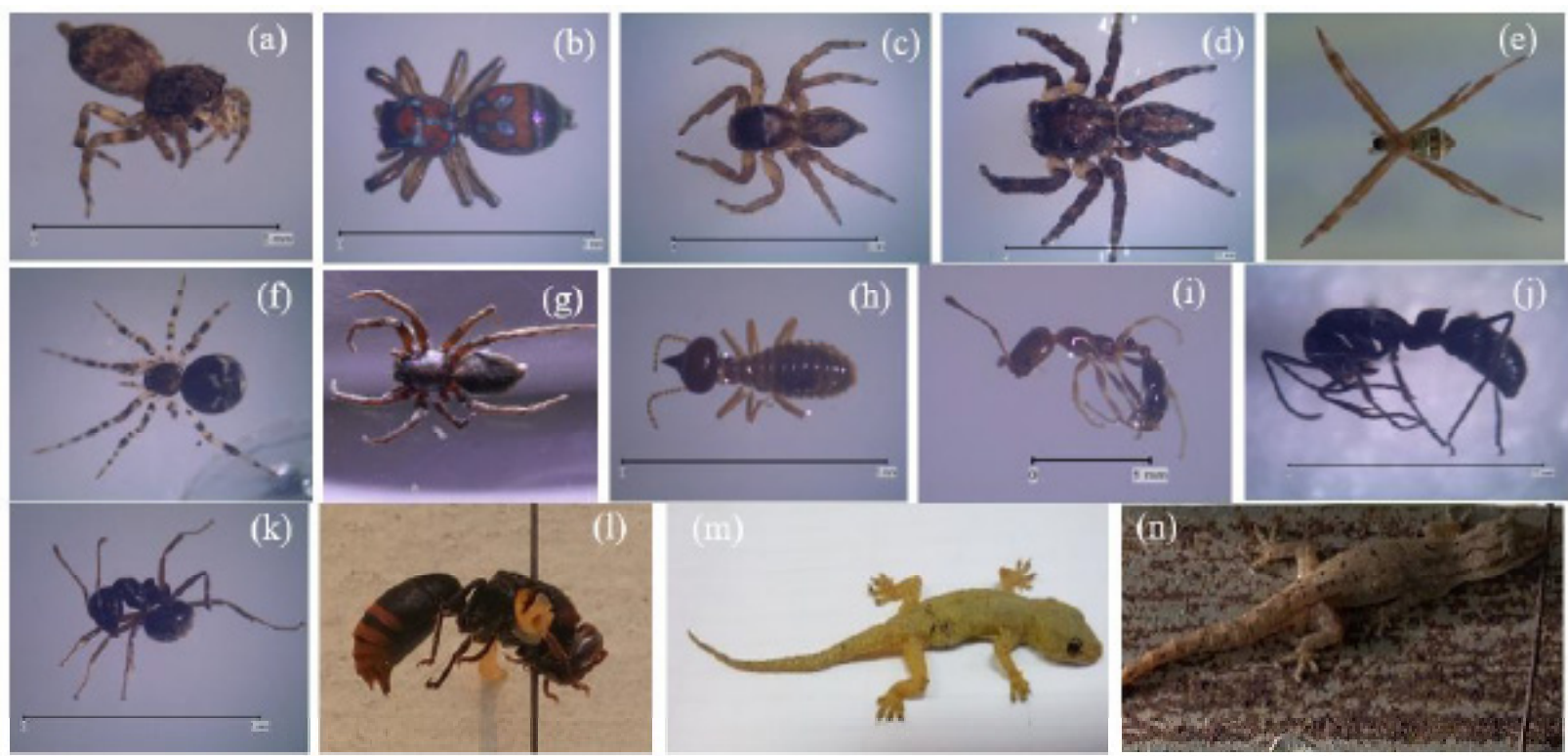

Gambar 1. Musuh alami lebah L. terminata. (a) Pseudeuophrys sp., (b) Heliophanus sp., (c) Argiope versicolor, (d) Plexippus paykuli, (e) Marpissa sp., (f) Parasteatoda tepidariorum, (g) Tegenaria sp., (h) Nasutitermes javanicus, (i) Paratrechina sp., (j) Polyrhachis sp., (k) Paratrechina longicornis (k), (1) Rhynchium haemorrhoidale, (m) Hemidactylus frenatus, dan (n) Hemidactylus garnotii 
ini sering ditemukan didinding dan ranting tanaman dengan menempel pada jaringnya.

Parasteatoda tepidariorum termasuk kedalam famili Theridiidae dengan tubuh didominasi warna hitam dan kuning dengan panjang $1.60 \mathrm{~mm}$. Mata berjumlah delapan yang tersusun dalam dua baris dengan pola 4-4, bagian posterior sejajar tampak putih atau perak, dan bagian anterior melengkung ke bawah. Sefalothoraks berwarna hitam kecoklatan berbentuk oval dengan sedikit menyempit dibagian anterior. Abdomen berbentuk bulat besar berwarna hitam dengan corak coklat kekuningan dan lebih besar dari sephalothorax. Tungkai berwarna hitam dengan bintik-bintik putih, terdapat duri duri halus, dan tungkai ketiga berukuran paling pendek. Spinneret berada diujung ventral abdomen (Gambar 1).

Tegenaria sp. termasuk kedalam famili Agelenida dengan tubuh berwarna kehitaman dengan panjang tubuh $11.55 \mathrm{~mm}$. Mata berjumlah delapan yang tersusun dalam dua baris dengan pola 4-4 dengan ukuran sama. Mata anterior tersusun lurus, sedangkan mata posterior sedikit melengkung kearah posterior. Sefalothoraks berwarna coklat kehitaman berbentuk oval dengan sedikit menyempit dibagian posterior. Abdomen berbentuk lonjong berwarna coklat kehitaman, bagian anterior abdomen tidak berhimpit pada sefalotoraks. Tungkai kecoklatan dengan ramburambut tebal. Spinneret berada diujung ventral abdomen (Gambar 1). Sering dijumpai di dinding dan ranting tanaman dengan menempel pada jaringnya.

Nasutitermes javanicus termasuk kedalam kelas Insekta, famili Termitidae yang memiliki kepala berwarna coklat, antena, lambrum, dan pronotum kuning pucat. Panjang tubuh $3.85 \mathrm{~mm}$, lebar tubuh $1.05 \mathrm{~mm}$, panjang kepala $1.11 \mathrm{~mm}$, dan lebar kepala $1.02 \mathrm{~mm}$. Bentuk kepala bulat dengan tonjolan mirip tanduk (nasute). Antena terdiri dari 11 segmen. Mandibula berbentuk melengkung dibagian ujungnya. Abdomen berwarna putih kekuning-kuningan dengan jumlah 10 segmen yang ditutupi rambut-rambut menyerupai duri (Gambar 1).

Paratrechina sp., Polyrhachis sp., dan Paratrechina longicornis termasuk kedalam famili Formicidae. Paratrechina sp. memiliki ubuh kecil berwarna coklat terang pada bagian kepala dan thorak dengan panjang tubuh $2.06 \mathrm{~mm}$. Panjang kepala $0.47 \mathrm{~mm}$, lebar kepala $0.28 \mathrm{~mm}$, dan panjang antena $0.83 \mathrm{~mm}$. Kepala berbentuk persegi panjang dengan mata kecil berwarna hitam. Pedicel dengan dua nodus, bagian depan berukuran lebih besar. Abdomen hitam kecoklatan berbentuk lonjong. Tungkai panjang berwarna coklat terang (Gambar 1). Polyrhachis sp.memiliki tubuh besar berwarna kehitaman sampai hitam pekat. Panjang tubuh 9.79 $\mathrm{mm}$, panjang kepala $2.85 \mathrm{~mm}$, lebar kepala $1.41 \mathrm{~mm}$, dan panjang antena $6.68 \mathrm{~mm}$. Kepala berbentuk oval, pedicel dengan satu nodus yang berukuran besar. Abdomen lonjong berwarna hitam kecoklatan. Terdapat duri-duri panjang berjumlah 4 pada thorak dan 2 buah pada pedicel. Tungkai panjang dengan duri besar di bagian ujung tibia (Gambar 1). Sedangkan Paratrechina longicornis memiliki tubuh berwarna hitam kecoklatan sampai kehitaman dengan beberapa rambut-rambut keputihan pendek. Panjang tubuh 2.32 $\mathrm{mm}$, panjang kepala $0.83 \mathrm{~mm}$, dan lebar kepala 0.56 $\mathrm{mm}$. Antena panjang kecoklatan dengan panjang 1.76 $\mathrm{mm}$. Segmen pertama masing-masing antena dua kali lebih panjang dari segmen selanjutnya. Abdomen bulat dan bagian dorsal kecoklatan. Tungkai sangat panjang berwarna coklat sampai kemerahan (Gambar $1)$.

Rhynchium haemorrhoidale termasuk kedalam famili Vespidae dengan tubuh berwarna hitam dengan panjang tubuh $16.31 \mathrm{~mm}$. Clypeus menonjol berwarna kemerahan. Mandibula panjang dan besar kemerahan dengan ujung meruncing. Genna dan antenna kemerahan. Thorak berwarna hitam tanpa rambutrambut halus dan posterior mesoscutum kemerahan. Sayap bagian tegula sampai stigma kehitaman dan bagian stigma sampai ujung sayap coklat kekuningan. Abdomen memiliki 6-7 tergit, tergit kedua tampak besar dan panjang dengan warna kemerahan dibagian ujungnya. Tungkai depan berwarna kemerahan (Gambar 1).

Hemidactylus frenatus memiliki tubuh berwarna abu-abu sampai coklat terang atau kekuningan dengan panjang tubuh $10 \mathrm{~cm}$. Perut berwarna keputihan. Sisik ekor halus dengan deretan duri besar yang mengelilingi beberapa bagian ekor. Jari dengan lamella yang tampak hanya setengah dari panjang jari dan tanpa selaput. Ekor berbentuk bulat memanjang dengan ujung runcing (Gambar 1). Sedangkan Hemidactylus garnotii memiliki tubuh pendek dan agak gemuk berwarna abu-abu gelap atau coklat. Kepala memiliki moncong yang panjang dan sempit. Perut berwarna kuning dengan punggung terdapat corak garis hitam dari moncong sampai tungkai belakang. Bagian dorsal terdapat garis-garis sempit dan membentang dari leher bagian dorsal sampai pangkal ekor. Ekor memiliki deretan seperti sisik berduri dibagian tepi lateral dan bersekat (Gambar 1).

Sebanyak 687 individu musuh alami yang ditemukan disekitar sarang L. terminata. Jumlah individu tertinggi yaitu Paratrechina sp. (512 individu), diikuti oleh $P$. longicornis (138 individu), dan $N$. javanicus (132 individu). Keragaman musuh alami pada koloni $L$. terminata yaitu $\left(H^{\prime}=1,129\right)$, indeks kemerataan $\left(\mathrm{J}^{\prime}=0.427\right)$, dan indeks Dominansi $(\mathrm{D}=0.633)($ Tabel 2). 
Tabel 2. Indeks keanekaragaman musuh alami lebah L. terminata

\begin{tabular}{llc}
\hline Famili & Spesies & Jumlah individu \\
\hline Salticidae & Pseudeuophrys sp. & 3 \\
& Heliophanus sp. & 1 \\
& Plexippus paykuli & 4 \\
Araneidae & Argispe versicolor & 2 \\
Theridiidae & Parasteatoda tepidariorum & 2 \\
Agelenidae & Tegenaria sp. & 4 \\
Termitidae & Nasutitermes javanicus & 1 \\
Formicidae & Paratrechina sp. & 132 \\
& Polyrhachis sp. & 512 \\
& Paratrechina longicornis & 12 \\
Vespidae & Rhynchium haemorrhoidale & 138 \\
Gekkonidae & Hemidactylus frenatus & 2 \\
& Hemidactylus garnotii & 2 \\
Jumlah Individu & 4 \\
Jumlah spesies & 687 \\
Index Shannon-wiener (H') & 14 \\
Index kemerataan (J') & 1,129 \\
Indek dominansi (D) & 0.427 \\
\hline
\end{tabular}

\section{PEMBAHASAN}

Hasil pengamatan yang telah dilakukan, ditemukan 14 spesies musuh alami L. terminata yaitu, Pseudeuophrys sp., Heliophanus sp., Argiope versicolor, Plexippus paykuli, Marpissa sp., Parasteatoda tepidariorum, Tegenaria sp., Nasutitermes javanicus, Paratrechina sp., Polyrhachis sp., Paratrechina longicornis, Rhynchium haemorrhoidale, Hemidactylus frenatus, dan Hemidactylus garnotii. Sebagaian besar musuh alami yang ditemukan merupakan predator lebah $L$. terminata. Hal ini didukung dengan data pengamatan yang menunjukkan bahwa sebagian besar kelas Arachnida dan Reptilia memangsa individu lebah $L$. terminata. Selain itu, famili Formicidae dan vespidae juga memangsa individu lebah dan mengambil madu didalam sarang lebah L. terminata. Famili Termitidae yang ditemukan tidak memangsa individu lebah namun koloni ini menempati sarang lebah sehingga dapat merusak sarang lebah. Berdasarkan penelitian Pangestika (2016), musuh alami pada koloni Trigona di Tasikmalaya dan Pasuruan, Indonesia, yaitu kecoa (Blattidae), kumbang (Platysoma leconti dan Carpophilus sp.), semut (Pheidole sp.), dan larva rayap yang ditemukan didalam kotak koloni Trigona.

Spesies laba-laba meliputi yang berhasil ditemukan terdiri dari 4 famili, meliputi Salticidae (Pseudeuophrys sp., Heliophanus sp., Plexippus paykuli, dan Marpissa sp.), Araneidae (Argiope. Versicolor), Agelenidae (Tegenaria sp.), dan Theridiidae (Parasteatoda tepidariorum). Labalaba aktif pada siang hari dan bergerak sangat cepat saat memangsa serangga (Foelix 1996). Umumnya habitat laba-laba terdapat di lingkungan dengan vegetasi kering yang masih alami, seperti lahan pertanian dan rerumputan (Subyanto et al. 1991). Hasil pengamatan menunjukkan bahwa labalaba sangat agresif memangsa individu lebah tak bersengat. Hal ini sesuai dengan laporan Roubik (2006), bahwa arachnids (Cryptocellus gamboa) termasuk simbiosis yang merugikan lebah tak bersengat, karena melemahkan dan memangsa individu lebah.

Spesies cicak (Hemidactylus frenatus dan Hemidactylus Garnotii) ditemukan pada siang hingga sore hari dan bersifat pasif. Berdasarkan pengamatan, warna tubuh cicak yang serupa dengan habitatnya menyebabkan tidak terlihat oleh lebah sehingga memudahkan untuk mendekati sarang dan memangsa lebah. Hal ini didukung bahwa sebagian besar makanan yang dominan dimangsa cicak adalah kelompok Diptera (Wafa 2007). Selain itu, Laporan Pangestika (2016), menyebutkan bahwa ditemukan telur cicak di dalam kotak koloni lebah tak bersengat. Hal ini diduga bahwa cicak termasuk musuh alami (predator) lebah tak bersengat.

Spesies semut (Paratrechina sp., Polyrhachis sp., dan Paratrechina longicornis) ditemukan didedaunan dan serasah yang aktif berjalan untuk menemukan makanannya. Menurut Ikbal et al. (2014), jumlah individu Paratrechina dipengaruhi oleh melimpahnya serasah dan gulma yang digunakan semut untuk beraktivitas dan bersarang. Semut pekerja Paratrechina bersifat omnivora, yaitu memakan serangga dan biji-bijian. Berdasarkan pengamatan bahwa semut sangat agresif menyerang individu L. terminata dekat pintu masuk sarang lebah. Semut memangsa bagian kepala dan toraks individu lebah $L$. terminata secara berkoloni. Jumlahnya yang banyak dan hidup berkoloni membuat semut menjadi predator kelompok serangga lainnya termasuk lebah L. terminata. Menurut Roubik (2006) lebah tak bersengat menggunakan resin di bagian mulut sarang untuk mencegah serangga kecil seperti semut masuk ke dalam sarang. Sesuai dengan laporan Lehmberg et al. (2008) dan Kumar et al. (2011) bahwa semut (Crematogaster difformis dan Paratrechina longicornis) merupakan predator utama di luar dan di dalam sarang lebah Trigona. Namun, koloni semut termasuk serangga yang tempat bersarangnya berasosiasi dengan lebah Trigona yang sebagian besar bersarang di pohon (Roubik 2006).

Selain itu, ditemukan spesies rayap (Nasutitermes javanicus) dan tawon (Rhynchium haemorrhoidale) di sarang $L$. terminata. Sarang rayap yang berada di bawah dan bersatu dengan sarang lebah, dapat mengganggu dan merusak sarang lebah. Rayap 
pekerja bersifat agresif dan mencari makan dengan menggerogoti kayu atau bahan berselulosa (Nandika 2003). Hal ini akan membahayakan keberadaan sarang lebah yang secara keseluruhan berbahan kayu. Keberadaan rayap secara tidak langsung dapat mempengaruhi aktivitas lebah dan komponen sarang. Lebah Tetragonula laeviceps meletakkan resin di jalur yang menghubungkan sarangnya dengan koloni rayap (Nasutitermes $\mathrm{sp}$.) (Lehmberg et al. 2008). Berdasarkan pengamatan terdapat spesies tawon yang masuk ke dalam sarang lebah tak bersengat. Hal ini dapat mengganggu aktivitas lebah, bahkan dapat membunuh individu lebah. Menurut Spradbery (1973), bahwa tawon memakan material tumbuhan berupa buah dan nektar namun, sebagian juga memangsa serangga. Sesuai laporan Kumar et al. (2011), bahwa semut dan tawon merupakan musuh alami lebah tak bersengat. Namun, Roubik (2006) melaporkan bahwa, koloni rayap (Nasutitermes) dan tawon termasuk organisme yang tempat bersarangnya berasosiasi dengan organisme lainnya. Berdasarkan hasil pengamatan bahwa koloni lebah $L$. terminata termasuk lebah yang tidak agresif dan cenderung penakut, sehingga musuh alami (predator) dapat dengan mudah masuk kedalam sarang. Keberadaan musuh alami di lingkungan sangat berpotensi membahayakan koloni lebah tak bersengat jika jumlahnya melebihi batas (Pangestika 2016).

Sistem pertahanan pada sarang lebah berupa resin digunakan sebagai mekanisme pertahanan terhadap predator (De Bruijn and Sommeijer 1997; Lehmberg et al. 2008; Duangphakdee et al. 2009; Leonhardt et al. 2010). Mekanisme pertahanan terhadap predator juga ditunjukkan oleh pekerja lebah tak bersengat dengan gerakan berdiri dan terbang (melayang) pada pintu masuk sarang, serta melakukan gigitan agresif (Roubik 2006; Lehmberg et al. 2008, Gruter et al. 2010). Organisme lain yang berada di dekat atau di dalam sarang lebah tak bersengat dianggap sebagai musuh (predator) (Gruter et al. 2010). Pada malam hari, beberapa spesies lebah tak bersengat menutup saluran masuk dengan lilin (Gruter et al. 2010). Selain itu, bagian sarang seperti involucrum (selubung resin) sangat penting sebagai sistem pertahanan dalam sarang. Menurut Roubik (2006), bahwa sarang koloni lebah tak bersengat dengan ketinggian tempat bersarang $100-200 \mathrm{~cm}$ di atas permukaan tanah sangat rentan serangan musuh alami karena keberadaan sarang dan sumber makanan yang berdampingan dengan predator.

Hasil indek keanekaragaman musuh alami pada koloni $\mathrm{L}$. terminata yaitu $\left(\mathrm{S}=14, \mathrm{H}^{\prime}=1.129\right.$,
$\left.\mathrm{J}^{\prime}=0.427\right) \quad($ Tabel 2). Yang mengindikasikan bahwa tingkat keanekaragaman yang tergolong stabil dengan tingkat kemerataan rendah. Dengan demikian dapat dikatakan bahwa keanekaragaman spesies musuh alami dengan kelimpahan yang sama atau hampir sama dan penyebaran spesies musuh alami tersebut tidak merata. Pada kelas Arachnida dan Reptilia menunjukkan jumlah individu lebih sedikit dibandingkan dengan kelas insecta. Nilai indeks dominansi musuh alami pada koloni $L$. terminata yaitu $\mathrm{D}=0.633$ yang mengindikasikan terdapat spesies musuh alami yang mendominasi. Kelas insekta sangat mendominasi berdasarkan jumlah individu yang ditemukan. Paratrechina sp. ditemukan sebanyak 512 individu dan Paratrechina longicornis (138 individu), sehingga dapat diasumsikan bahwa populasi spesies ini melimpah dan dapat menjadi musuh alami utama pada lebah L. terminata.

\section{KESIMPULAN}

Musuh alami lebah Lepidotrigona terminata yang ditemukan sebanyak 687 individu, 14 spesies yang tegolong dalam 3 taksa, yaitu Arachnida (7 spesies), Reptilia (2 spesies), dan Insekta (5 spesies). Sebagian besar keseluruhan spesies musuh alami merupakan predator karena bersifat melemahkan dan membunuh individu lebah tak bersengat. Musuh alami yang mendominasi yaitu kelas insecta meliputi spesies Paratrechina sp. (512 individu), Paratrechina longicornis (138 individu), dan Nasutitermes javanicus (132 individu). Spesies semut banyak ditemukan disekitar sarang lebah mengindikasikan bahwa semut merupakan salah satu predator utama lebah tak bersengat khususnya $L$. terminata. Indeks Keanekaragaman ( $\mathrm{H}^{\prime}$ ) didapatkan nilai 1,129 hal ini berarti tingkat keanekaragaman spesies musuh alami tergolong stabil atau sedang.

\section{UCAPAN TERIMA KASIH}

Penulis mengucapkan terima kasih kepada Staf Laboratorium Divisi Biosistematik dan Ekologi Hewan, Depatemen Biologi, Institut Pertanian Bogor yang telah membantu dalam identifikasi.

\section{DAFTAR PUSTAKA}

Banziger H, Pumikong S, Srimuang K. 2011. The remarkable nest entrance of tear drinking Pariotrigona klossi and other stingless bees nesting in limestone cavities (Hymenoptera: Apidae). Kans Entomol Soc 84:22-35.

Borror DJ, Triphelone CA, Johnson NF. 1992. Pengenalan Pelajaran Serangga. S Partosordjono. Yogyakarta: Gadjah Mada Press. 
Chinh TX, Sommeijer MJ, Boot WJ, Michener CD. 2005. Nest and colony characteristics of three stingless bee species in vietnam with the first Description of the nest of Lisotrigona carpenteri (Hymenoptera: Apidae: Meliponini). Journal of the Kansas Entomological Society 78:363-372.

De Bruijn LLM, Sommeijer MJ. 1997. Colony foraging in different species of stingless bees (Apidae, Meliponinae) and the regulation of individual nectar foraging. Insect Soc 44:350- 47.

Duangphakdee O, Koeniger N, Deowanish S, Hepburn HR, Wongsiri S. 2009. Ant repellent resins of honeybees and stingless bees. Insect Soc 56:333-339.

Estes J, Crooks K, Holt R. 2001. Predators ecological role of. Encyclopedia of biodiversity 4:857-878.

Foelix RF. 1996. The Biology of Spiders. New York: Oxford University Press.

Gruter C, Karcher MH, Ratnieks FLW. 2010. The natural history of nest defence in a stingless bee, Tetragonisca angustula (Latreille) (Hymenoptera: Apidae) with two distinct types of entrance guards. Neotrop Entomol 40:55-61.

Hamid SA, Salleh MS, Thevan K, Hashim NA. 2016. Distribution and morphometrical variations of stingless bees (Apidae: Meliponini) in Urban and Forest Areas of Penang Island, Malaysia. J Trop Resour Sustain Sci 4:1-5.

Ikbal M, Putra NS, Martono E. 2014. Keragaman semut pada ekosistem tanaman kakao di Desa Banjaroya Kecamatan Kalibawang Yogyakarta. Jurnal Perlindungan Tanaman Indonesia 18:79-88.

Inoue T, Salamah S, Abbas I, Yusuf E. 1985. Foraging behavior of individual workers and foraging dynamics of colonies of three sumatran stingless beess. Res Popul Ecol 27:373392.

Kelly N, Farisya MSN, Kumara TK, Marcela P. 2014. Species diversity and external nest characteristics of stingless bees in Meliponiculture. J Trop Agric Sci 37:293 - 298.

Krebs, CJ. 1999. Ecological Methodology. Second Edition. New York: An imprint of Addison Wesley Longman, Inc.

Kumar MS, Singh AJAR, Alagumuthu G. 2012. Traditional beeskeeping of lebah tak bersengat (Trigona sp.) by kani tribes of Western Ghats, Tamil Nadu, India. Indian $J$ Tradit Knowledge 11:342-345.

Lehmberg L, Dworschak K, Nico B. 2008. Defensive behavior and chemical deterrence against ants in the stingless bee genus Trigona (Apidae, Meliponini). Journal of Apicultural Research 47:17-21.
Leonhardt SD, Zeilhofer S, Bluthgen N, Schmitt T. 2010. Stingless bees use terpenes as olfactory cues to find resin sources. Chem Senses 35:603-611.

Michener CD. 2013. Pot-Honey: A Legacy of Lebah tak bersengat. Vit P, Pedro SRM, Roubik DW. Editor. New York (US): Springer Pr.

Nandika D, Rismayadi Y, Diba F. 2003. Rayap, Biologi dan Pengendaliannya. Surakarta: Muhammadiyah University Press.

Pangestika NW. 2016. Additional Nest Structure and Flower Constancy of Stingless Bees (Hymenoptera: Apidae) [Tesis]. Bogor, Indonesia: Institut Pertanian Bogor.

Rasmussen C. 2008. Catalog of the Indo-Malayan/Australasian Lebah tak bersengats (Hymenoptera: Apidae: Meliponini). Zootaxa 1935:1-80.

Roubik DW. 2006. Stingless bee nesting biology. Apidologie $37: 124-143$

Schwarz HF. 1939. The Indo-Malayan species of Trigona. Bull AMNH 76:83-141.

Smith DR. 2012. Key to workers of Indo-Malayan stingless bee. For use in the Lebah tak bersengat Workshop 1:1-42.

Shackleton K, Toufailia HA, Balfour NJ, Nascimento FS, Alves DA, Francis L, Ratnieks W. 2015. Appetite for Selfdestruction: suicidal biting as a nest defense strategy in Trigona Stingless bees. Behav Ecol Sociobiol 69:273-281.

Spradbery JP. 1973. Wasps: an Account of the biology and natural history of solitary and social wasps. Washington: University of Washington Press.

Starr CK, Sakagami SF. 1987. An extraordinary concentration of stingless bee colonies in the Philippines, with notes on nest structure (Hymenoptera: Apidae: Trigona spp.). Insec Soc 34:96-107.

Strauss U, Human H, Gauthier L, Crewe RM, Dretemann V, Park CWW. 2013. Seasonal prevalence of pathogens and parasites in the savannah honeybee (Apis mellifera scutellata). Invertebrate Pathology 114:45-52.

Subyanto, Sulthoni A, Siwi SS, Lilies C. 1991. Kunci Determinasi Serangga. Yogyakarta: UGM.

Wafa Z. 2007. Komposisi Makanan pada Tiga Spesies Cicak (Cosymbatus platyurus) Schneider, Hemidactylus franatus Dumb. Bibr dan Gehyra mutilate Weign) Melalui Analisis Makanan Dalam Lambung [Skripsi]. Bogor, Indonesia: Institut Pertanian Bogor 